\title{
Can Money Symbolize Acknowledgment? How Victims' Relatives Perceive Monetary Awards for Their Emotional Harm
}

\author{
Liesbeth Hulst • Arno J. Akkermans
}

Received: 17 March 2011 / Accepted: 9 September 2011 /Published online: 24 November 2011

(C) The Author(s) 2011. This article is published with open access at Springerlink.com

\begin{abstract}
Legal systems differ markedly on how they treat the emotional harm suffered by close family members of crime or accident victims. This paper reports the results of two empirical studies examining how citizens whose child, partner, or parent was killed or seriously injured as a result of violent crime or tort (secondary victims) perceive a monetary award for their own non-economic harm relating to the death or injury of their loved one. The objective of our research was to test the Dutch legislator's assumption that a (modest) monetary award for secondary victims' emotional harm can have a meaningful symbolic value by providing recognition and satisfaction. Until then, no compensation was available for such harm under Dutch law. In addition, we examined whether victims' relatives preferred standardization or individuation in determining the amount of the award, how they evaluated the amount, and the manner in which such awards might be offered. In a first quantitative survey study conducted in the Netherlands, 726 secondary victims were asked for their evaluations of such awards for the emotional harm they suffered as a result of the death or injury of their family member. We also asked our representative sample about their actual experience of the legal process in order to put their evaluations of such awards into context. In a second qualitative study, conducted in Belgium, interviews were held with 14 secondary victims who had actually received
\end{abstract}

L. Hulst $(\bowtie) \cdot$ A. J. Akkermans

Faculty of Law, VU University Amsterdam,

Boelelaan 1105,

$10781 \mathrm{HV}$, Amsterdam, the Netherlands

e-mail: 1.hulst@vu.nl

L. Hulst · A. J. Akkermans

Amsterdam Interdisciplinary Center of Law and Health,

Amsterdam, the Netherlands an award for their own emotional harm under Belgian law (study 2). Results suggest that secondary victims regard an award for emotional harm as a positive gesture and may interpret it as helping to satisfy relatives' psychological concerns by seeing it, for example, as an acknowledgment of loss and responsibility. Overall findings suggest that victims' relatives may be seeking acknowledgement of their emotional losses and the norm violation.

Keywords Bereavement · Personal injury · Tort . Compensation $\cdot$ Restorative justice

The death or severe injury of a child, spouse, or parent is one of the most stressful life events. Close family members of victims may experience grief, psychological distress, a period of adjustment, loss of identity, and family cohesion, while also being at a higher risk of depression and anxiety disorders (e.g., Lehman et al. 1993; Middleton et al. 1997; Stroebe et al. 2008). Close relatives of victims may even make more negative cognitive interpretations of the harmdoer's intentions and responsibility for the offense and experience more negative affect than the primary victims themselves (Green et al. 2008). How people feel treated after a traumatic event may well affect how they recover. The extent to which an injured victim or a survivor experiences positive reactions from society that acknowledge the victim's state and situation may perhaps enhance recovery from posttraumatic stress disorder (Maercker and Müller 2004).

This paper examines how close relatives of those killed or seriously injured as a result of a tort or violent crime perceive a monetary award for the emotional harm they suffered as a result of the death or severe injury of their loved one. We investigated whether victims' relatives 
actually felt a need to receive a monetary award for their own emotional harm and whether they thought that a (modest) monetary award could have a meaningful symbolic value by providing them with acknowledgment. These assumptions formed the basis for a Dutch legislative proposal introducing a right to a financial award in order to provide "recognition and satisfaction" for emotional losses suffered by a narrowly defined circle of close relatives of people killed or severely injured in crimes or accidents for which another person was liable. The Dutch Bill explicitly stated that its aim was not to offer real compensation as no monetary award could make up for the harm in question.

Two other main focuses of our research were how victims' relatives thought the award should be offered (in order to meet the aim of providing acknowledgment), as well as whether they preferred standardization over individuation in determining the amount of the award. We examined the Dutch legislator's line of reasoning that it is better to provide victims' relatives with a fixed, uniform sum rather than force them to go through difficult and lengthy discussions about the "right" amount since money cannot compensate for these losses anyway. Our research was commissioned by the Dutch Ministry of Justice and requested by the Dutch Senate.

The Dutch Bill and our research were based on the central assumption that victims' relatives are not only motivated by instrumental (e.g., monetary) interests but also by non-instrumental (e.g., non-monetary) concerns, and we examined whether an award could help meet these non-instrumental concerns. Such a view of human nature is accepted in social psychology (Miller 1999; Tyler and Lind 1992). Our approach differed, however, from the line taken in some of the literature based on economic approaches of tort law, in which people are essentially viewed as rational economic actors driven by self-interest. ${ }^{1}$

More specifically, we examined whether victims' relatives felt that an award could help meet secondary victims' non-instrumental (or non-pecuniary, psychological, emotional) needs and motivations that have been identified in existing (mainly English language) literature on what tort and crime victims and their families want. In other words, we investigated whether secondary victims perceived an award as contributing to, for instance, recognition of the harm caused to the primary victim and the family, acknowledgment of responsibility for the harm, and attention and respect for the secondary victim as a person (study 1). We inferred that these were important noninstrumental needs and motivations of victims' relatives

\footnotetext{
${ }^{1}$ This literature focuses on how to calculate the level of compensation for non-economic harm based on insurance theory, e.g., Avraham 2005. Compare further deterrence literature, e.g., Posner and Sunstein (2005).
}

from (a) an earlier systematic review (in Dutch) of 33 empirical studies of needs of crime victims (Ten Boom and Kuijpers 2008, referring to Baurmann and Schädler 1991; Feldthusen et al. 2000; Maguire and Kynch 2000; see also for relatives of crime victims, Wortman et al. 1997); (b) an earlier review (in Dutch) of existing international empirical studies and literature relevant to the needs of tort victims (Huver et al. 2007, including, e.g., Bismark et al. 2006; Hensler et al. 1991; Lind et al. 1990; Lind and Tyler 1998; Shuman 1994); and (c) a previous Dutch exploratory qualitative study based on semi-structured interviews with 43 primary and 18 secondary victims of tort. A more detailed discussion of these earlier literature reviews and the exploratory study is beyond the scope of the present paper.

Below we will explain the Dutch Bill in more detail. This is followed by an overview of our research questions and our two studies. Firstly, we will briefly discuss whether monetary compensation to close relatives of tort and crime victims is allowed in various jurisdictions.

\section{Background: Jurisdictional Differences in Allowing Damages for Emotional Harm to Victims' Relatives}

Legal systems differ vastly in how they treat non-economic losses of close relatives of victims of crime or tort resulting from the death or severe injury of a loved one. The main idea behind decisions not to allow damages for such harm is that the harm to those relatives is too remote and/or that such emotional harm cannot be expressed in monetary terms. In other words, money cannot restore the family to a pre-harm condition.

A majority of European countries, ${ }^{2}$ however, do recognize damages for non-pecuniary harm suffered by close family members consequent on the wrongful death of the primary victim, although the systems applied vary (Bona et al. 2005, p. 422). A substantial number of European countries also allow damages for non-pecuniary harm suffered by close family members living with a permanently disabled primary tort victim (Bona et al. 2005, p. 426). ${ }^{3}$ The range of eligible persons varies, but usually the spouse, children, and parents of a minor can receive monetary compensation for non-pecuniary harm because of the emotional impact that the injury to the primary victim has had on them (Bona et al. 2005). Most countries make no distinction between grief and (non-economic) loss of relationship, consortium, society, companionship, care,

\footnotetext{
${ }^{2}$ Including the UK, Ireland, Greece, Bulgaria, Iceland, Turkey, Liechtenstein, France, Italy, Spain, Portugal, Switzerland, Luxembourg, Belgium, Serbia, Slovenia, and Croatia

${ }^{3}$ Including France, Italy, Spain, Portugal, Switzerland, Luxembourg, Belgium, Serbia, Slovenia, and Croatia
} 
love, and moral support (Bona et al. 2005). In addition, the relative is generally not required to suffer from a medically diagnosed psychiatric condition (Bona et al. 2005). Only a minority of European countries (the Netherlands, Germany, and Denmark) do not allow any such claims for compensation of emotional harm to victims' relatives.

Only a minority of US states officially permit damages for grief to be awarded to a victim's surviving relatives after wrongful death (e.g., McClurg 2005; Oswald and Powdthavee 2008; Posner and Sunstein 2005). However, courts in a substantial number of US states allow damages to be awarded for loss of society and companionship (McClurg 2005; Posner and Sunstein 2005). In Australia, tort law does not make any provision for non-pecuniary damages to be awarded to family members of those killed or severely injured in crimes or accidents in the absence of recognized medical injury of the family member (Luntz 2006).

\section{Dutch Legislative Proposal}

In the Netherlands, we have regularly seen cases being taken to court by people seeking non-pecuniary compensation after the wrongful death or severe injury of their child, but these have generally been to no avail. ${ }^{4}$ In the case of wrongful death, dependents can only sue for lost maintenance. As a child has no income and no dependants, its parents will only receive reimbursement of funeral expenses. The Dutch legislator saw this as indicative of a divergence between what members of the public who had experienced such a loss felt that the law should be and what the Dutch legal system held that the law required and should provide. This led to a Bill introducing the right to a financial award for emotional losses suffered by a narrowly defined circle of close relatives of those killed or severely injured in crimes or accidents for which another person was liable. These relatives (partners, children, and parents) with a close family or comparable relationship to the primary victim are also referred to here as secondary victims. Under the Bill, the person liable for the loss should pay a fixed amount (initially set at $10,000 €$, which was equivalent to around USD 13,500 in February 2011) to the victim's family member. In practice, these costs would almost always be borne by the harm-doer's insurer, or by a violent crime victim compensation fund. As mentioned above, the Bill explicitly stated that money could not truly make up for the emotional losses of victim's relatives. The aim of

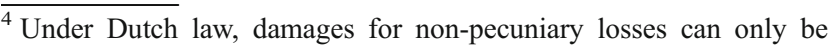
awarded to close relatives of the primary victim if the relative witnessed the incident in which the primary victim was injured, and this resulted in the relative suffering from a medically diagnosed psychiatric illness. The conditions imposed are, however, relatively strict, and most claims are denied.
}

providing such an award was to offer recognition and satisfaction to victims' relatives and not to offer actual compensation for relatives' emotional harm. Consequently, the use of the word "compensation" in this article is not meant to signify making up for such non-compensable harm. The legislator's line of reasoning in opting for a fixed, uniform sum was that relatives should be spared from having to go through discussions about the "right" amount since money cannot actually compensate for their losses. Discussions in Dutch legal literature over the previous decade focused mainly on whether to set fixed or variable sums for this new type of award.

\section{Overview of the Research}

The two main research questions we sought to answer were as follows:

1. Do close family members of those killed or severely injured as a result of a tort or violent crime actually feel a need to receive a monetary award for emotional harm following the death or severe injury of their loved one?

2. Do these family members feel that receiving such monetary award for emotional harm would help satisfy secondary victims' non-instrumental (or non-pecuniary, psychological, and emotional) needs?

This can therefore be seen as an empirical study of whether "such awards [for non-economic suffering can serve] as tools for reconstructing meaning in the face of suffering," as suggested by Schatman and Sullivan (2010, p. 190). The question of whether secondary victims see a monetary award as an acceptable and even helpful response to their emotional losses is also interesting, given the psychological theory and evidence on "taboo trade-offs." This theory posits that people consider life, health, and love to be sacred values. In other words, things we must treat as infinitely important and which are qualitatively different from money (Fiske and Tetlock 1997; Tetlock et al. 2000). We wondered whether quantifying the suffering caused to the family by the lost life or lost health of a loved one might also be seen as an inappropriate "taboo trade-off" or even provoke indignation and anger in victims' families.

In our research, we also examined secondary victims' preferences for a fixed sum vs. a variable sum in order to test the legislator's assumption that secondary victims would obtain more relief from a fixed sum. We also examined how relatives regarded the intended modest amount of the award (research questions 3). In addition, we asked for respondents' thoughts on how the award should be offered (research question 4). Given that the aim of the award is to symbolize acknowledgment, we also examined the mode of offering because previous research 
showed that claimants may experience the process of seeking compensation of economic losses as burdensome (Huver et al. 2007). Lastly, we investigated how our main outcomes related to a number of demographic and explanatory variables such as relationship characteristics, injury severity, and blame assigned to the harm-doer (research question 5). We also sought to examine differences between fatal and non-fatal injuries regarding main outcomes.

\section{Two Studies}

The Dutch Ministry of Justice commissioned us to conduct a large-scale quantitative survey among close family members of tort and violent crime victims in the Netherlands (study 1) because the Dutch Senate wanted to know what those falling within the scope of the Dutch Bill actually thought about an award for their own emotional harm. We were also assigned to conduct a study of qualitative interviews with close relatives of victims who had actually received an award for their own emotional harm, as allowed under Belgian law (study 2).

The objective of study 1 , the main focus of our research and this paper, was to answer the above five research questions. The key objective of study 2 was to gain insight, by learning from experience in Belgium, into how awards for emotional harm should be determined and offered (research questions 3 and 4). An additional objective of study 2 was to complement and enrich the data acquired in study 1 with qualitative data on the experiences of actual recipients of awards for emotional harm suffered as a result of the death or severe injury of a family member (Johnson et al. 2007; Sale et al. 2002; Straus and Corbin 1998). Severe recruitment difficulties resulted, however, in the Belgian sample in study 2 being smaller than intended.

\section{Hypothetical vs. Actual Award Following Actual Emotional Harm}

In study 1, Dutch secondary victims were asked for their views on an as yet non-existent (under Dutch law) right to a monetary award for their own emotional harm. As explained below, any distortions from being asked about a hypothetical award were minimized: (a) because our respondents had suffered actual losses and (b) through certain preventive measures. In addition, as explained above, we conducted study 2 which involved actual recipients of such awards for emotional harm.

Preventive Measures In study 1, we first examined how victims' relatives experienced various aspects of the legal process following the death or injury of their loved one (including the process of seeking compensation for economic losses, their experience with the police and the Public Prosecutor's Office and any contact with the offender). We also asked victims' relatives how these various aspects of the legal process affected their emotional recovery and which of the elements of the legal process they felt were, or would have been, most beneficial to their emotional recovery (such as swifter settlement of financial losses, acknowledgment of responsibility by the offender or attentive treatment by the police).

We avoided asking respondents to speculate about how a monetary award for emotional harm would make them feel personally. Instead, we asked them whether they had felt a lack of attention for their personal emotional losses during the legal processes and only then examined their opinions and interpretations of an award for their own emotional losses. That is, we asked secondary victims whether they felt they should receive such an award (research question 1) and then how they interpreted such award in the light of the needs and motivations of secondary victims in general (research question 2). In order to avoid overestimation of the effect of an award, we did not focus on asking Dutch respondents to predict how the actual receiving of such award would fulfill their personal needs or make them feel personally. Items not directly relating to respondents themselves have also been shown to limit social desirability bias (Fisher 1993).

Actual Losses Research into affective forecasting has shown that people are generally able to identify the type of response they will have to an event and whether it will be positive or negative but are less able to predict the intensity and duration of their emotional responses (Wilson and Gilbert 2005; Blumenthal 2005). The fact that our participants had experienced the actual death or injury of their family member in the past minimized the potential overestimation of the effect of an award (for identified causes of this forecasting error, see Wilson and Gilbert 2005; Gilbert et al. 1998). Our Dutch respondents were not predicting their emotional reactions to a future, hypothetical loss; such predictions tend to be affected by people's failure to anticipate their natural tendency to make the best of bad outcomes (Wilson and Gilbert 2005; "immune neglect"). The fact that our respondents were asked about harm actually suffered in the past will also have diminished their tendency to underestimate the extent to which other events will influence their thoughts and feelings ("focalism"). These relatives had already had to deal psychologically with their past traumatic loss and had experienced the influence of other events - including the legal process they went through - and thus might be less inclined to attribute 
their "resilience" to external agents, such as compensation or an apology (Gilbert et al. 1998). It has also been shown that when people imagined being compensated, they required less compensation for events that had taken place in the past than for identical events taking place in the future (Caruso et al. 2008). In addition, people may perhaps be less prone to overestimate the symbolic value of an award to alleviate non-economic suffering as opposed to economic losses (Robbennolt 2003, for apologies).

\section{Study 1: Survey in the Netherlands}

For the purpose of answering our research questions (Q 1-5), we developed a questionnaire that was completed online by 726 citizens of whom a close relative had died or become severely and permanently injured in a violent crime or other incident for which another party was liable in tort (traffic or workplace accident or medical malpractice, all referred to jointly as accidents).

\section{Method in Study 1}

\section{Participants}

Our main source for selecting these secondary victims was an existing internet panel of a large market research organization (TNS NIPO Panel). This comprises a nationally representative sample of over 48,000 households in the Netherlands. Contacts from over 47,000 households filled in our screening instrument designed to identify secondary victims falling within the scope of the legislative proposal. The inclusion criteria were (a) respondent is/was the partner, parent, or child of the primary victim; (b) the primary victim was killed, or severely and permanently injured; (c) in a violent crime or accident for which another party was liable in tort $^{5}$; and (d) secondary and primary victims share(d) the same home. We included Dutchspeaking respondents over the age of 18 and incidents taking place between 1990 and 2007.

All family members of severely injured victims and 55\% of surviving relatives included in study 1 came from the TNS NIPO Panel. However, there were insufficient close relatives of fatally injured parties within the Panel to meet our initial aim of also examining differences between fatal and non-fatal incidents. Additional surviving relatives were

\footnotetext{
5 Thus, our sample included intentional harms (violent crimes) and harms for which tort liability existed on the basis of fault (negligent or even reckless conduct), or on the basis of strict or qualitative liability (such as motorists liable for injuries to cyclists or pedestrians under the age of 14).
}

therefore recruited through alternative channels. ${ }^{6}$ These accounted for the remaining $45 \%$ of the relatives of fatal victims and $5 \%$ of the total sample included in study 1 . The sociodemographic characteristics of the group of respondents included in study 1 were largely similar to those of the general population of the Netherlands, although citizens with a lower level of education were under-represented in both the TNS NIPO Panel and our group of respondents included in study $1(11.9 \%$ vs. $23.3 \%$ in the general population). Our respondents also included slightly more women $(56.4 \%)$ and more citizens over the age of $50(45 \%$ vs. $40.6 \%$ in the general population) and slightly fewer under the age of $35(21.9 \%$ vs. $29.2 \%$ in the general population), but it seems reasonable to assume that the entire population of parents, partners, and children of accident and crime victims may differ from the general population in this same way. TNS NIPO takes measures to ensure demographic diversity and to prevent selectivity of response within its Panel. In addition, a potential overrepresentation or under-representation of certain groups in the TNS NIPO Panel (such as relatives of fatally injured victims) may also have been partly overcome by our using alternative channels to recruit participants. All in all, the recruitment methods used enabled us to obtain the most representative sample that was practically achievable.

\section{Materials}

Screening Instrument Respondents were screened for eligibility on the basis of whether they would fall within the range of persons entitled to an award for emotional harm to victims' relatives under the Dutch Bill (see the above inclusion criteria), using five items.

Questionnaire A multidisciplinary research team constructed separate items and a number of scales for answering the five research questions. The contents of the questionnaire were revised on the basis of expert evalua-

\footnotetext{
${ }^{6}$ A total of 23 surviving relatives of accident victims were recruited through (a) Victim Support Netherlands, which sent out 450 invitation letters to a random sample from a population of 8,000 surviving relatives of fatal victims of traffic accident between 2000 and 2007, where the family had had contact with Victim Support at least once (which is more or less standard after major accidents), and (b) personal injury victims' legal representatives, who sent out 20 invitation letters. Eight surviving relatives of violent crime victims were recruited through three different (regionally spread) organizations of family members of victims of violence, which sent out electronic invitations to their members. We acknowledge that the 23 surviving relatives recruited outside the TNS NIPO Panel may be more self-selected. Analyses were also, however, run without including this group and showed no noteworthy deviations (except that the level of blame assigned to the harm-doer no longer significantly affected main outcomes, see research question 5).
} 
tions and pre-tests. No factor analyses were conducted of any of the scales of the questionnaire. The questionnaire consisted of 90 items for surviving relatives and 99 items for relatives of injured victims. For non-fatal incidents, additional items were included to assess injury severity. Most items were rated on a seven-point response scale ranging from 1 (definitely not) to 7 (definitely so), with an additional response category of no reply/not applicable. The questionnaire used for relatives of parties injured in accidents was also used for relatives of violent crime victims, but with some minor modifications in terminology.

Research Question 1: Need for an Award The extent to which secondary victims actually feel a need to receive a monetary award for emotional harm relating to the death or severe injury of their family member was measured using a scale consisting of six items (Cronbach's $\alpha=0.85$ ). Actual scale items can be found in the "Appendix" (Table 3).

Research Question 2: Appreciation of an Award The extent to which secondary victims feel that receiving a monetary award for emotional harm would help satisfy relatives' nonmonetary needs was measured on a scale consisting of 13 items (Cronbach's $\alpha=0.92$ ). Actual scale items can be found in Table 2 ("Results and Discussion of Study 1" and "Results and Discussion of Study 2" sections). Most items from this scale asked whether an award for emotional harm would help satisfy needs of relatives of victims in general (abstracting from any effects on respondents' personal needs or emotional experience), using insights from existing literature about the needs and motivations of litigants/victims (Huver et al. 2007; Ten Boom and Kuijpers 2008) and from a qualitative Dutch study of tort victims and their relatives' experience of the legal compensation process (Huver et al. 2007). The questionnaire explained that the award would not in practice be paid by the offender, but by the latter's insurer or, in the case of relatives of crime victims, by the Violent Crimes Compensation Fund.

\section{Background of Relatives' General Needs and Experiences} in Legal Process (Used in Respect of Research Question 2)

We also wanted to be able to put respondents' perceptions of an award for emotional harm into a context of their general experiences and needs in the legal compensation and/or criminal processes they went through following the death or severe injury of the primary victim. Items in this section asked about aspects of the legal process (did you experience this: yes/no) and how that aspect had (in the event of a "yes" answer) or could have (in the event of "no") contributed to their emotional recovery (using the standard sevenpoint scale or no reply/not applicable). Once again we relied on existing literature on needs and motivations of litigants/victims for the items relating to aspects of the legal process (Huver et al. 2007; Ten Boom and Kuijpers 2008). We also asked respondents to express which three aspects were or would have been most important for their emotional recovery. A final item asked whether they felt that these other three aspects were more important for their emotional recovery than a right to an award for their emotional harm. With the exception of the final item, items in this section were presented prior to the items in the scales assessing the need for, and evaluation of, emotional harm awards. More details about this section are set out in the "Appendix."

Research Question 3: Amount and How to Determine the Amount Respondents' opinions on the amount of the compensation were measured using two items (see "Results and Discussion of Study 1" and "Results and Discussion of Study 2" sections). Respondents were also asked for their preferences for one of three alternative modes of determining the amount of the emotional harm award. Before respondents were asked to choose their preferred mode, they were given descriptions of these three alternative modes (including their main advantages and disadvantages), followed by items asking them to weigh the pros and cons of the different modes. Descriptions and items relating to the three modes of determining the amount were randomly presented.

Research Question 4: Mode of Offering the Award Respondents' evaluations of various modalities of offering the award were measured using 12 items (see Table 4 of the "Appendix").

Research Question 5: Explanatory Variables Lastly, we examined how our main outcome measures were influenced by a large number of demographic and explanatory variables (see "Results and Discussion of Study 1" and "Results and Discussion of Study 2" sections).

\section{Procedure}

Participants received a letter by (e-)mail inviting them to participate in research about needs of victims' relatives. The fact that the research also included research into monetary awards for emotional losses to relatives was not disclosed. The questionnaire was administered online and respondents could complete it on their own computers at a time convenient to them. Panel respondents received a modest payment of $3 €$. After completing the questionnaire, respondents recruited from outside the Panel were offered a $10 €$ gift voucher. 


\section{Statistical Methods}

We performed multivariate analyses of covariance (MANCOVA) on mean scores on three dependent variables (i.e., the scales assessing need for, and appreciation of, awards for emotional harm and the single item asking for participants' opinions on an amount of 10,000 €). We chose MANCOVA and follow-up ANCOVAs because we were instructed to examine group differences between surviving relatives of fatal victims and relatives of those who had been seriously injured. We adjusted for differences across groups in gender, age, education, and income by using these variables as covariates. To examine the effects of explanatory variables on our main outcome measures, we performed other MANCOVAs and follow-up ANCOVAs, again using demographic variables as covariates, for relatives of victims with fatal and non-fatal injuries separately.

Results and Discussion of Study 1

\section{Cases Included}

In the analyses, data were used from 463 respondents falling within the narrowly defined circle of secondary victims who would be entitled to an award under the Dutch Bill. These comprised 391 relatives of severely injured victims and 72 relatives of fatal victims (see Table 1). Results relied on a dataset that was also used in an earlier report in Dutch to the Dutch Ministry of Justice (Akkermans et al. 2008).

\section{Research Question 1: Do Secondary Victims Feel a Need for Such Award?}

The mean score on the six-item scale assessing whether secondary victims actually felt a need to receive a monetary award for emotional harm was 4.81 , with a standard deviation of 1.42 (1, strongly disagree, to 7, strongly

Table 1 Study 1 -number of close family members of severely and fatally injured victims included in the analyses and their distribution across incident categories

\begin{tabular}{lcc}
\hline Type of incident & \multicolumn{2}{l}{ Relatives of } \\
\cline { 2 - 3 } & Injured victims & Fatal victims \\
\hline Traffic accident & 238 & 40 \\
Workplace accident & 68 & 6 \\
Medical malpractice & 42 & 16 \\
Violent crime & 43 & 10 \\
Total & 391 & 72 \\
\hline
\end{tabular}

Adapted from Akkermans et al. (2008). agree). This mean deviated significantly from the middle of the response scale, $t(460)=12.25, p<0.001$. Outcomes show that a vast majority of secondary victims responded slightly positively to the possibility of receiving such an award (see Fig. 1). Only for $4 \%$ of respondents did the categorized mean scores on the scale assessing the need for emotional harm awards fall in the two lowest response categories. This indicates that a small minority strongly felt that they should not receive such an award (see "Appendix," Table 3, for means and standard deviations on individual items of this scale).

\section{Research Question 2: Does an Award Help Meet Psychological Concerns?}

The mean score on the 13-item scale assessing whether these family members felt that receiving a monetary award for emotional harm would help satisfy psychological needs of secondary victims (in general) was 5.22, with a standard deviation of 1.17 (1, strongly disagree, to 7, strongly agree). This mean score deviated significantly from the middle of the response scale, $t(461)=22.29, p<0.001$.

As Fig. 2 shows, for $3 \%$ of the secondary victims, the categorized mean on this scale fell within the lowest two categories of the seven-point scale indicating that they expected such an award to have a strongly negative effect on the fulfillment of their psychological needs. For $43 \%$ of respondents, the categorized mean fell within the highest two response categories - and for $75 \%$ in the highest threeindicating that they expected an award for emotional harm to help satisfy secondary victims' psychological needs.

Secondary victims seemed to regard the award primarily as:

- Acknowledgment of the harm-doer's responsibility for the incident and ensuing harm: "A right to compensation for emotional loss means that the responsible party 'acknowledges his fault' $(M=5.27)$; 'is liable' $(M=5.77)$; 'is forced to realize the emotional burden on family members'." $(M=5.64)$.

- Recognition by the legal system of the emotional harm and as fair treatment of victims' family members: "A right to compensation for emotional loss would mean that: 'the Dutch legal system acknowledges the emotional outcome of the accident for family members' $(M=5.89)$; 'the Dutch legal system treats family members fairly"." $(M=5.54)$. See Table 2 for the means on individual scale items.

Background for Research Question 2: Relatives' Main Justice Concerns and How These Relate to an Award Research question 2 concerned whether an award would help meet secondary victims' psychological concerns. We 
Fig. 1 Study 1 -frequency distribution of categorized means on the scale assessing need for emotional harm awards, in percentages. Adapted from Akkermans et al. 2008

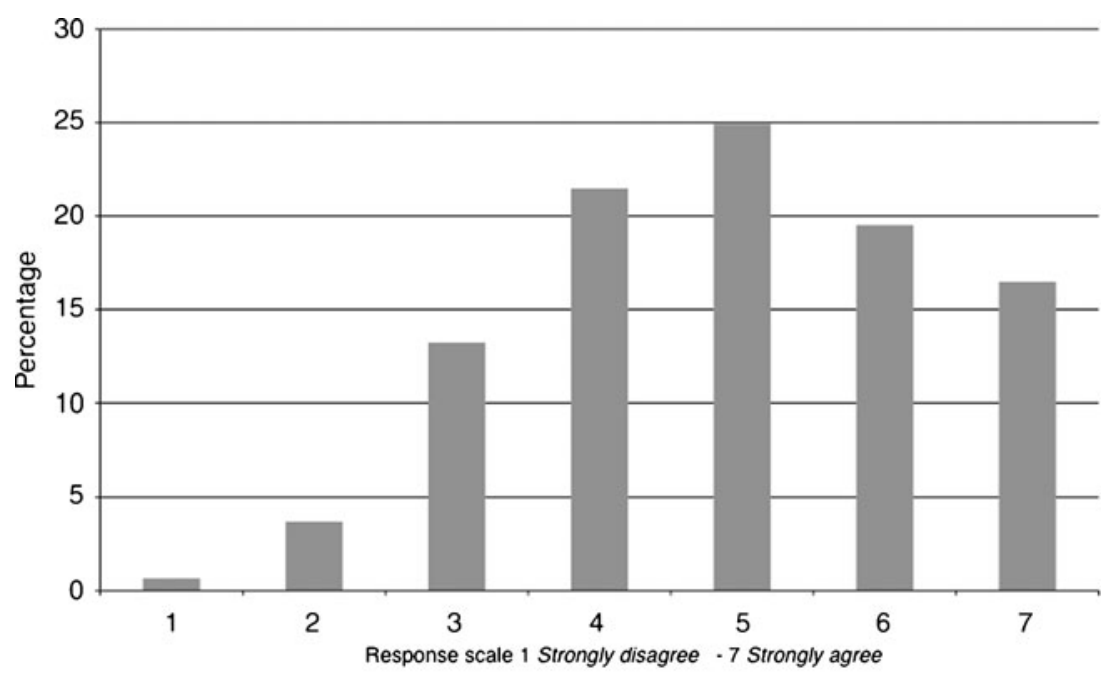

Categorized means 1 between 1 and 1.5, 21.5 and 2.5, 32.5 and $3.5,43.5$ and 4.5, 54.5 and 5.5. 65.5 and 6.5 , and 76.5 and 7 consequently wanted to know our respondents' main concerns and motivations in respect of the legal processes they had gone through following the death or injury of their loved one (compensation claims for economic losses and/or criminal procedures). More specifically, therefore, we also asked our respondents to state which three aspects relating to the legal process had, or would have, contributed most to their emotional recovery (individual Top Three needs; see "Appendix" for more details). ${ }^{7}$

The subgroup of relatives of tort victims stated that it was important for their own emotional recovery:

- That the pecuniary damage was "indeed settled" $(12.7 \%$; $M=5.09, \mathrm{SD}=1.82)$ "in a smooth and swift manner" $(15.1 \% ; M=5.29, \mathrm{SD}=1.86)$ "by the harm-doer's insurer"

- That the responsible party "acknowledges his/her fault" (12.8\%; $M=4.97, \mathrm{SD}=1.95)$, "apologizes" $(11.4 \% ; M=$ $5.08, \mathrm{SD}=1.96)$, "shows empathy for the consequences" $(10.1 \% M=5.18, \mathrm{SD}=1.86)$, and "realizes the consequences for the victim" $(8.1 \% ; M=4.80, \mathrm{SD}=1.88)$

In other words, secondary accident victims desired swifter compensation of economic losses (27.8\% of responses on Top Three needs) but also an acknowledgment of responsibility and the ensuing losses by the harm-doer $(42.4 \%$ of their responses in the Top Three needs).

\footnotetext{
${ }^{7}$ How often various aspects were mentioned in individual Top Three needs is indicated in parentheses. In addition, we report how each aspect was regarded as contributing to emotional recovery on a seven-point scale; the higher the number, the more important this aspect was for emotional recovery. The numbers of occasions on which aspects were mentioned as most, second-most, and third-most important were added and given the same weight. The use of other weights barely changed the order of the nine most important aspects. We cannot report the percentages of respondents expressing specific categories of needs.
}

As far as their emotional recovery was concerned, the subgroup of relatives of violent crime victims deemed it most important for the offender to be was "found guilty" (18.1\%; $M=5.12, \mathrm{SD}=1.78)$ and "punished" $(17.5 \% ; M=4.67, \mathrm{SD}=$ 2.04 ) by "a criminal court," as well as "that action is taken to prevent similar future crimes" $(9.4 \% ; M=4.87, \mathrm{SD}=1.60) .{ }^{8}$

We then re-presented each respondent's individual Top Three of needs previously rated as most important to their emotional recovery, but with the addition, at place four, of a right to an award for emotional harm. We asked respondents once again to rank the three aspects they considered most important to their own emotional recovery. For $19 \%$ of relatives of injured victims and $11 \%$ of relatives of fatal victims, an emotional harm award then entered the individual Top Three, while for the remaining respondents their individual Top Three remained unchanged. Hence, these findings indicated that an award was expected to contribute less to emotional recovery than the other aspects/needs and that receiving a monetary award for emotional harm was not respondents' primary concern. Our other findings that respondents interpreted the emotional harm award as an acknowledgment of fault/liability and losses by the harmdoer may lend some support to the view that such an award could indirectly help to meet secondary tort victims' main concerns for acknowledgment of fault and recognition of harm.

\footnotetext{
${ }^{8}$ This group also rated correct treatment by the Public Prosecutor's Office $(M=5.55, \mathrm{SD}=0.95)$ and attentive treatment by the police $(M=$ $5.41, \mathrm{SD}=1.40$ ) as important for their emotional recovery (although these aspects did not make it into the overall Top Three needs). However, secondary violent crime victims felt that an apology from the offender $(M=3.67, \mathrm{SD}=2.45)$ or the offender's expression of empathy for the consequences $(M=3.24, \mathrm{SD}=2.29)$ would not contribute to their emotional recovery (cf. "acknowledges his fault," $M=4.48, \mathrm{SD}=2.12$ ).
} 
Fig. 2 Study 1 -frequency distribution of categorized means on the scale assessing appreciation of awards for emotional harm, in percentages. Adapted from Akkermans et al. 2008

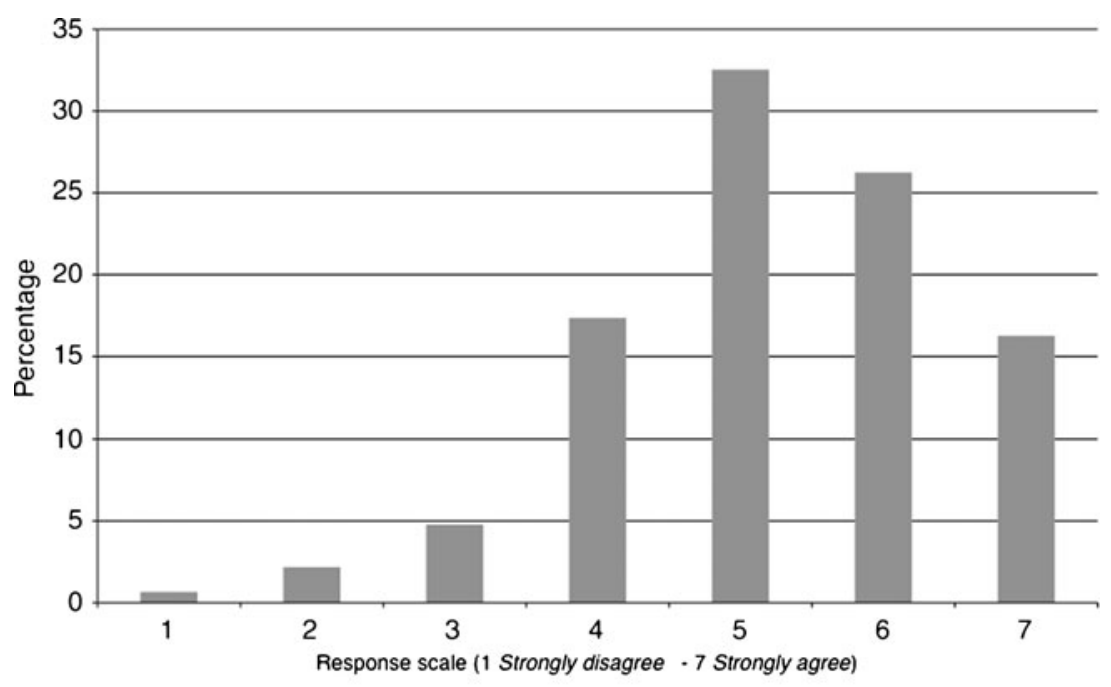

Categorized means 1 between 1 and 1.5, 21.5 and 2.5, 32.5 and 3.5, 43.5 and 4.5, 54.5 and 5.5, 65.5 and 6.5 , and 76.5 and 7

\section{Research Question 3: Do Secondary Victims Prefer Standardization or Individuation of Amounts, and How Do They Evaluate the Amount?}

We asked respondents for their preference for one of three alternative modes of determining the amount of the emotional harm award. ${ }^{9}$ These three modes were a fixed amount (the Dutch Bill included a fixed, uniform amount), a variable amount (to be determined for each individual case), or a standardized amount (based on tables specifying amounts for different categories of relationships and injuries). A total of $36.1 \%$ of the respondents preferred a variable amount, while $28.3 \%$ of respondents indicated a preference for a standardized amount and $15.8 \%$ preferred a fixed amount. A total of $19.9 \%$ of respondents answered Don't know.

Responses on additional items weighing the advantages and disadvantages of the three modes of determining the amount also suggested that respondents found individuation more important than swift resolution and not having to negotiate. ${ }^{10}$

Regarding the amount of the monetary award, we asked participants "If a fixed amount is chosen, what do you think of $€ 10,000$ as a fixed amount?," using a seven-point scale ranging from 1, much too low, to 7, much too high. The mean score on this item was $3.5(\mathrm{SD}=1.58)$, which significantly deviated from the middle of the seven-point scale, $t(445)=-6.69, p<0.001$. A total of $45 \%$ of the sample had a neutral view on an amount of $10,000 €(4$, middle of scale), while $28 \%$ of the sample regarded this amount as too

\footnotetext{
${ }^{9}$ Relatives of injured persons and surviving relatives did not differ significantly in their answers to this question, $\chi^{2}(3)=4.37, p=0.225$.

${ }^{10}$ For example, "I find it important that my personal circumstances are taken into account, even if this leads to having to negotiate and to a lengthier settlement process" $(M=5.15, \mathrm{SD}=1.68$, on the standard seven-point scale).
}

low and $8.5 \%$ as too high. Over $13 \%$ of the sample chose not to answer this question. We found that surviving relatives were more likely than relatives of seriously injured persons to regard the amount of $10,000 €$ as being too low, multivariate $F(3,342)=9.14, p<0.001$, and univariate $F(1$, $344)=27.14,<0.001$ ( $M$ s adjusted for gender, age, education, and income, 2.51 vs. 3.70). ${ }^{11}$

We also asked "Can you try to indicate what amount you would find appropriate in your situation?" Participants could fill in amounts (which were categorized for the purposes of the analyses), or choose No reply. On average, relatives of injured persons indicated an amount between $10,000 €$ and $25,000 €$, while surviving relatives indicated an average amount of between $50,000 €$ and $100,000 €$. A total of $13 \%$ of relatives of injured victims and $22 \%$ of surviving relatives did not complete this open-ended item.

\section{Research Question 4: How Should the Award be Offered?}

Participants seemed to appreciate emphasis being placed on the symbolic nature of the award. Written communication by the insurance company or compensation fund expressing empathy seemed to be appreciated by participants, but a home visit could also be appropriate (see Table 4 of "Appendix," for means and standard deviations on items about modalities of offering). A large majority of secondary tort victims also appreciated receiving a letter from the harm-doer $(M=5.61$, $\mathrm{SD}=1.59$, with $63 \%$ choosing the highest two response categories and $5.2 \%$ choosing the lowest two response categories) but not a home visit. Relatives of violent crime

\footnotetext{
${ }^{11}$ Surviving relatives and relatives of injured persons did not differ significantly with respect to their means on the scale assessing need for emotional harm awards and on the scale assessing appreciation of emotional harm awards, as follow-up ANCOVAs indicated.
} 
Table 2 Study 1-mean scores and standard deviations on separate items of scale assessing appreciation of awards for emotional harm $(n=463)$

\begin{tabular}{|c|c|c|}
\hline & $\begin{array}{l}\text { Means } \\
\text { (standard } \\
\text { deviations) }\end{array}$ & $\begin{array}{l}\text { Times "no } \\
\text { reply/not } \\
\text { applicable" }\end{array}$ \\
\hline $\begin{array}{l}\text { To me, a right to compensation for } \\
\text { emotional loss means some } \\
\text { recognition. }\end{array}$ & $5.11(1.77)$ & 12 \\
\hline $\begin{array}{l}\text { Compensation for emotional loss to } \\
\text { family members could help in coming } \\
\text { to terms with the emotional consequences } \\
\text { the accident had for me. }\end{array}$ & $4.47(1.89)$ & 12 \\
\hline $\begin{array}{l}\text { I find compensation for emotional loss } \\
\text { an appropriate manner to pay attention } \\
\text { to the emotional consequences for } \\
\text { family members. }\end{array}$ & $5.0(1.73)$ & 12 \\
\hline $\begin{array}{l}\text { Apart from my personal preferences, I } \\
\text { think it is a good idea for other family } \\
\text { members to get the opportunity to receive } \\
\text { compensation for emotional loss. }^{\text {a }}\end{array}$ & $5.52(1.59)$ & 9 \\
\hline $\begin{array}{l}\text { Apart from my personal preferences, I } \\
\text { think compensation for emotional } \\
\text { loss would contribute to the } \\
\text { emotional recovery of other } \\
\text { family members. }\end{array}$ & $5.25(1.62)$ & 9 \\
\hline $\begin{array}{l}\text { A right to compensation for emotional } \\
\text { loss for family members... }\end{array}$ & & \\
\hline $\begin{array}{l}\text {...means that the responsible party } \\
\text { acknowledges his fault }\end{array}$ & $5.27(1.74)$ & 3 \\
\hline $\begin{array}{l}\text {...means that the responsible party is } \\
\text { liable }\end{array}$ & $5.77(1.34)$ & 7 \\
\hline $\begin{array}{l}\text {...means that the responsible party is } \\
\text { forced to realize the emotional burden } \\
\text { on family members }\end{array}$ & $5.64(1.56)$ & 5 \\
\hline $\begin{array}{l}\text {...means that the responsible party is } \\
\text { being asked to make a sacrifice }\end{array}$ & $5.06(1.77)$ & 7 \\
\hline $\begin{array}{l}\ldots \text { would mean that the Dutch legal } \\
\text { system acknowledges the emotional } \\
\text { outcome of the accident for family } \\
\text { members }\end{array}$ & $5.89(1.26)$ & 8 \\
\hline $\begin{array}{l}\ldots \text { would mean that the Dutch legal } \\
\text { system treats family members fairly }\end{array}$ & $5.54(1.42)$ & 7 \\
\hline $\begin{array}{l}\ldots \text { would help the social environment } \\
\text { to recognize the emotional consequences } \\
\text { of the accident for family members }\end{array}$ & $4.77(1.71)$ & 11 \\
\hline $\begin{array}{l}\ldots \text { would help the social environment to } \\
\text { see that someone else (and not the victim) } \\
\text { is responsible for the accident }\end{array}$ & $4.74(1.77)$ & 10 \\
\hline
\end{tabular}

Standard deviations appear in parentheses. All ratings were done on a seven-point scale (the higher the number, the higher the expected level of contribution of this award to needs). The same items used for relatives of parties injured in accidents were also used for relatives of violent crime victims, but with minor modifications in terminology ("crime" instead of "accident"; "offender" instead of "responsible party"). Adapted from Akkermans et al. (2008).

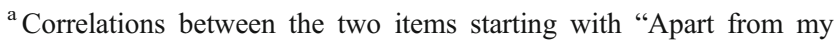
personal preferences" and the scale assessing appreciation of emotional harm awards did not deviate from the mean correlations between other scale items and this scale. This finding may help disqualify the alternative explanation that respondents simply gave socially desirable answers. victims, however, did not welcome any contact with the offender. Participants seemed to appreciate emphasis being placed on the symbolic nature of the award.

\section{Research Question 5: Variables Influencing Main Results? ${ }^{12}$}

When respondents assigned more blame to the harm-doer, this was associated with an increased need for, and a higher appreciation of, an award for emotional harm. ${ }^{13}$ Interestingly, however, we found no effects of blame on opinions regarding the amount of $10,000 €$, or on the amounts that respondents themselves stated to be appropriate.

For non-fatal injuries, a greater impact of the injuries on the daily life of the primary and secondary victims was associated with an increased need for, and with greater appreciation of, such award. ${ }^{14}$ Importantly, no association was found between the impact of the injuries and relatives' sense that $10,000 €$ was the right amount.

We found no differences between violent crime and accidental harm or between categories of family relationships (i.e., whether the victim was the child, partner, or parent of the respondent) with respect to the main outcomes (only tested for the group of relatives of injured persons). Finally, no significant effects were found for the remaining explanatory variables ${ }^{15}$ on any of the main outcomes. With respect to demographic variables (age, gender, education, and financial income), minor yet significant effects on our main outcome measures were found for education and age.

\section{Study 2: Interviews in Belgium}

As mentioned earlier, the key objective of study 2 was to learn from experience in Belgium regarding how awards for emotional harm should be determined and offered (research questions 3 and 4). An additional goal was to complement

\footnotetext{
$\overline{12}$ These main outcomes were respondents' means on the scales assessing need for and appreciation of emotional harm awards and on responses regarding the amount.

${ }^{13}$ For both non-fatal incidents, multivariate $F(3,337)=3.85, p=0.01$, univariate $F(1,339)=11.00, p=0.001$ and $F(1,339)=5.05, p=0.025$, respectively, and fatal incidents, multivariate $F(3,37)=3.30, p=0.031$, univariate $F(1,39)=7.62, p=0.009$ and $F(1,39)=8.12, p=0.007$, respectively.

${ }^{14}$ Multivariate $F(3,337)=19.78, p<0.001$; for need univariate $F(1$, $339)=58.09, p<0.001$; and for appreciation univariate $F(1,339)=$ $28.49, p=0.025$. To assess the extent to which the injuries impacted on the victim and the relative (injury severity or impact), we used a sixitem scale, Cronbach's $\alpha=0.75$.

${ }^{15}$ Number of hours the family member spent taking care of the victim, the estimated total amount of pecuniary damage, the emotional closeness between the family member and victim at the time of the incident, and the time interval since the incident.
} 
and enrich the data acquired in study 1 with qualitative data on the experience of actual recipients of such awards.

\section{Method in Study 2}

\section{Participants}

We conducted semi-structured interviews with 14 secondary victims in Belgium who had received monetary compensation for the emotional harm they suffered as a result of the death or severe injury of a close relative (adults, Flemish-speaking, with incidents occurring between 1990 and 2007). ${ }^{16}$ Surviving relatives were over-represented (11), especially those of car crash victims (nine). Our sample was small due to severe recruitment difficulties (which may stem from the fact that our target population was relatively small in number and may also have been hesitant to participate in research about their traumatic experience).

\section{Materials and Analyses}

Two psychologists conducted semi-structured interviews, while two other social scientists analyzed transcripts. Analyses consisted of labeling statements in which participants expressed their experience of receiving an award for emotional harm relating to the death or injury of a relative. Data were analyzed according to a process of open-, axial-, and selective coding (Strauss and Corbin 1998). Firstly, the transcripts were labeled with five main elements (based on the research questions): "amount of the award," "manner of determining," "manner of offering," "experience of the compensation for emotional harm," and "how was the compensation spent." Secondly, certain subcomponents were added during the analysis (such as "kind of recognition" and "not making up for suffering"). Eventually, no new themes emerged and data saturation was reached. Thirdly, all the transcripts were re-analyzed on the basis of the new list of labels. Subcomponents appearing in at least three of the 14 interviews were used and described. Discrepancies between the two analyzers were resolved through discussion. The computer software program Atlas.ti (version 5.2) was used for assigning and analyzing the labels.

\section{Results and Discussion of Study 2}

In study 2, interviewees were asked how the amount of the compensation had been determined and how they had

\footnotetext{
$\overline{{ }^{16} \text { Participants }}$ were recruited through a Belgian market research agency, which sent out a screening questionnaire among its own panel and contacted all Flemish institutions and associations dealing with these victim groups. In addition, 20 Belgian lawyers who were members of a European network of lawyers specializing in personal injury cases were asked to send invitation letters to their clients.
}

experienced this. ${ }^{17}$ A clear theme in the qualitative study in Belgium was that interviewees considered it of crucial importance that they should not have to negotiate the amount of the compensation. Any such negotiations were characterized as debates about the monetary value of the victim's life. Interviewees stated that such debates would have been morally offensive and overly distressing. A Belgian surviving relative said that "People should not be forced into bargaining about life, its monetary values ... it angers me, bargaining the way you would at a flea market." Some interviewees made comparisons on how somebody else's pain appeared to be worth more than their own. These findings seem to conflict with the preference of most respondents in study 1 that individuation information would be taken into account in determining the amount of the award.

We asked interviewees how the award had been offered to them. It appeared that they had often been notified of the award in a strictly business-like manner (sometimes only by being sent a copy of the letter sent to their lawyers). "It was written in cold rationalistic terms. 'You are receiving this because ...' The letter was the same as the letter for the damage to the car." "The letter referred to a file number, just a file number. Not a person. And nothing emotional. A 'cold fish' letter." As another relative said:

The letter included wording such as 'with reference to' rather than something like 'in view of the murder of your daughter on that date, we have decided to issue a payment in satisfaction, of this and that amount'. It could also be done in more humane, warm wording. They ought to mention the name of the child rather than 'Re: file number'.

The thread running through the responses was a desire for a more personal approach, with reference to what had happened rather than just to a file number.

Study 2 also indicated that the offering of compensation for emotional harm was best organized separately from any settlement of pecuniary damages. If such an award is presented as just one of the items in the final financial settlement, the special meaning attached to the award may fail to be conveyed.

Interviewees were also asked about their experience of receiving compensation for emotional harm. They stated that receiving this compensation had made them feel recognized and supported in the loss they had personally suffered and that this had helped them to come to terms

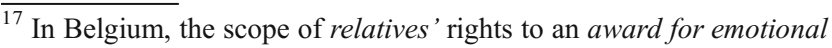
harm is defined by case law. There is a non-binding, indicative table of standardized amounts (based on case law and varying between relationship categories and fatal vs. non-fatal). The standard amount applying after the death of a child or partner is also $10,000 €$, but courts are free to diverge from this. Belgian interviewees had experienced different people receiving different amounts, but most interviewees did not seem to have negotiated on the amount.
} 
with their loss. A bereaved parent said "I see this compensation more as showing compassion with the suffering I went through." At the same time, however, interviewees stated that their grief could not in itself be financially compensated as money could not bring back their child or spouse and that money could not make the pain of losing a child or spouse disappear. With respect to "spending," it appeared that most participants spent the money in a manner specifically relating to the deceased (a family memorial, for example).

\section{General Discussion}

This work fills a gap in that it is the first empirical study of how close relatives of those killed or severely injured through tort or violent crime interpret and evaluate the symbolic properties of a monetary award for emotional harm suffered as a result of the death or serious injury of a family member. Our research sought to test the assumptions underlying proposed legislation in the Netherlands that the provision of a modest, uniform sum could symbolize recognition and satisfaction to victims' relatives. In this general discussion, we first examine secondary victims' perceptions of an award for emotional harm. We then go on to discuss that the manner in which an award is offered seems to be of crucial importance in fulfilling the aim of providing acknowledgment. Subsequently, we discuss whether secondary victims preferred uniform or variable sums, as well as their evaluations of the amount. Since our key question was whether a monetary award could provide acknowledgment to victims' relatives, we also wanted to establish relatives' main concerns and motivations regarding the legal process they had gone through following the death or injury of their loved one (compensation claims for economic losses and/or criminal procedures). The present findings may be of interest to legislators and policymakers around the world when considering how to address the emotional harm suffered by victims' families.

\section{Close Relatives' Perceptions of Awards for Emotional Harm}

The results of both our quantitative and qualitative empirical studies indicated that secondary victims regard the offering of a monetary award for emotional harm as a positive rather than offensive response to a death or severe injury caused. Only a small minority strongly felt that they should not receive such award (hence, relatives should be free to refuse an award).

This research also shed light on how a monetary award for emotional harm was perceived to be both positive and helpful. Our findings suggested that most respondents regarded an award as helping to meet secondary victims' emotional needs. ${ }^{18}$ Victims' relatives seemed to view such an award as a means to an end-in other words, to the end of helping to satisfy primary emotional needs - rather than as an end in itself. Results of study 1 indicated that secondary victims interpreted the award as (implicit) acknowledgement by the legal system of the family's emotional losses and as fair treatment of the victim's family. They also regarded this compensation as inter alia (implicit) acknowledgment by the harm-doer of his fault/ liability and of the emotional losses suffered by the family. The notion that the power of an award lies not in its monetary but in its symbolic significance was also reflected in our findings on the amount and in the finding that most secondary victims did not see an award for emotional harm in itself being among the most important things for their emotional recovery. Respondents most often stated that receiving acknowledgment of responsibility and/or recognition of the ensuing losses (from the harm-doer-at least after unintentional injuries, study 1) would have been most important to their emotional recovery. Findings in study 1 indicated that respondents seemed to regard this award as providing just that message of acknowledgment of responsibility and recognition of losses (by the harm-doer and the legal system). ${ }^{19}$ Hence, the provision of an award for emotional harm may perhaps indirectly help to satisfy primary needs of victims' relatives.

Distortions attributable to the Dutch respondents being asked about a hypothetical award were minimized by preventive measures and by the fact that our respondents had suffered actual losses. We acknowledge that our Dutch respondents' perceptions on the acceptability of awards for emotional harm may have been influenced by the fact that the questionnaire did not frame the award in a "marketpricing scheme" (i.e., it stated that the Bill recognized that money could not truly make up for these losses). However, the findings from the Belgian recipients' experience also suggested that receiving monetary compensation for emotional harm made them feel recognized and supported in their losses, although we should be cautious about these findings because study 2 used a qualitative method and the sample was small.

In conclusion, our quantitative (and qualitative) research indicated that tort and crime victims' relatives view the provision of a monetary award for emotional harm as a

\footnotetext{
${ }^{18}$ Needs that have been identified in existing literature on what (litigating) crime and accident victims and their families want and which were also consistent with the needs our respondents themselves expressed.

${ }^{19}$ A possible explanation could be that victims' relatives may be motivated by a desire to be seen positively by others and to feel good about themselves (cf. Risen and Gilovich 2007).
} 
positive gesture, conveying a symbolic message of recognition of loss and acknowledgment of responsibility. This potentially symbolic power of such an award is interesting, given that previous research indicated that survivors' perceptions of social acknowledgment may be related to their psychological adaptation to the traumatic stressor (Maercker and Müller 2004). There may of course be alternative, less compensation-centered ways to address secondary victims' emotional needs, such as by means of apologies or other expressions of concern. However, a monetary award may be the only legally enforceable remedy.

Value Is in the Gesture: Manner of Offering Awards for Emotional Harm

Our research suggested that a beneficial effect of the money could depend on the way secondary victims interpret the gesture. Findings from both studies suggested that it is important for the emotional harm award to be offered in a personal, respectful, and considerate manner and for the special meaning of the money to be emphasized. The results of the Belgian interviews illustrated that people wanted the offering of the award to be accompanied by an acknowledgment of what had happened to their family member, preferably worded in humane, warm terms.

Our findings indicated that victims' relatives appreciated the offering of an award being combined with a statement that the award was by no means intended to make up for the loss as this was obviously incompensable and instead was merely intended as a symbolic gesture, expressing recognition of this loss. In addition, our overall findings suggested that the symbolic function of an award for emotional harm would be strengthened if the person or organization offering the money paired this with (a) an explicit acknowledgment of the harm-doer's responsibility for causing the death or injury of the primary victim and (b) an expression of empathy with the loss. Although this notion was not directly tested in our research, we found that these two elements (responsibility-taking by the harm-doer and empathy with loss) were of primary concern to secondary accident victims (see findings on Top Three needs). These elements may also be regarded as the two main elements of an apology (Nadler and Liviatan 2006; Schönbach 1990). The notion that offering money is more effective if accompanied by a message expressing the taking of responsibility and showing empathy in response to even unintentional (economic) harm is supported by existing research in social psychology (e.g., Okimoto and Tyler 2007, even when coming from a "group representative" of the harm-doer; Schmitt et al.
2004; Struthers et al. 2008). Such affirmation may also ease any moral distress caused by a monetary value being placed on the death or severe injury of a loved one (cf. Robbennolt et al. 2003). In this respect, developing and using protocols for offering awards for emotional harm (to be paid by insurers or victim compensation funds) may be helpful.

The notion that injured parties are also sensitive to the interpersonal message communicated by the manner in which they are compensated (cf. Okimoto and Tyler 2007) was not previously a subject of debate in Dutch legal literature. Our findings on the importance of the manner in which monetary awards are offered may also be relevant with respect to compensation of other non-economic (and even economic) harm.

\section{Uniform vs. Variable Sums}

A majority of respondents in study 1 expressed a preference for some individuating information to be taken into account in determining the amount of the award (36.1\% and 28.3\%). Nevertheless, a substantial percentage of respondents also indicated a preference for some sort of standardization in determining the award (15.8\% and $28.3 \%)$. A clear theme in study 2 was that Belgian interviewees found it crucially important not to have to negotiate on the amount as that would have been morally offensive and distressing (cf. Fiske and Tetlock 1997; Tetlock et al. 2000). In this respect, it should also be noted that respondents in study 1 stated that swift resolution of the economic damage was of primary importance to their emotional recovery.

A plausible explanation of these mixed findings might be that the preference expressed by most Dutch participants for a degree of individual information in determining the amount was not borne out by actual experience (of negative aspects of variable amounts). However, Hadfield's (2008) report on the experiences of the 11 September Victim Compensation Fund (VCF) also revealed that claimants valued individual judgments on the amount above a quick financial award. Hensler (2003) also reported that payment by the VCF of equal amounts for pain and suffering was not regarded as important in comments from victims' survivors (and the general public). Perhaps litigants perceive a pre-set uniform monetary amount as being less able to "value" the losses they have personally suffered (Posner and Sunstein 2005). ${ }^{20}$

One implication of our overall findings is that even when using uniform amounts and out-of-court or administrative forms of claim settlement, it could also be important to

\footnotetext{
${ }^{20}$ Any system of awards for emotional harm would additionally raise issues of eligibility (see also Hensler 2003).
} 
address claimants' non-monetary concerns (for recognition of personal losses and acknowledgment of the violation of norms) through the manner in which the award is offered (cf. Hadfield 2008).

In addition, designing a system in which amounts are varied on the basis of "objective" factors could be a way of trying to accommodate any potential preference for individuation of amounts, while also attempting to prevent offensive and lengthy debates. In study 1 , however, we found no basis for varying amounts (for example, relationship category, blame assigned to the harm-doer, or injury severity) other than a difference between relatives of fatal victims and injured victims in their sense of the "right" amount. In this respect, it is also interesting that we found that more blame and a greater impact of the injuries were both associated with a greater need for and higher appreciation of an award, but not with a sense that the amount of the award should be higher.

Together, our results lend some support to the notion that a modest amount of $10,000 €$ would not be perceived as inappropriate by the majority of relatives of severely injured victims, although their own preferences were on average higher. For surviving relatives of fatal victims, however, $10,000 €$ certainly appeared to be too low. The validity of our measures regarding the amount of the award may perhaps be compromised as our respondents seemed to find it difficult to place a monetary value on emotional loss suffered (see in study 1: the high percentage of noncompletion on items concerning the amount, the finding that $45 \%$ of respondents chose the midpoint response option when asked how they evaluated $10,000 €$, and the findings in study 2 about respondents not wanting to negotiate the amount).

Our research was not aimed at examining how to calculate levels of damages for non-economic harm resulting from the death or injury of a loved one. This focus can be found in other literature based on economic approaches of tort law (e.g., Avraham 2005; Mulder 2009, for reviews on insurance theory; see also Oswald and Powdthavee 2008; Posner and Sunstein 2005; Sunstein 2008 on, for example, hedonic adaptation, but cf. Swedloff and Huang 2010). Our findings tie in with these and other debates on limitation of tort awards (on the basis of other economic grounds put forward in that literature) in the sense that our findings indicated that victims' relatives are seeking for their emotional losses and the norm violation to be acknowledged and that modest amounts and/or apologies may be a viable way of addressing these non-monetary concerns.

In summary, our results do not provide clear answers as to whether uniform amounts (fixed or standardized) are better than variable amounts. However, our findings lend support to the notion that even modest uniform amounts may be better as a means of addressing the psychological concerns of victims' families than the awarding of no damages following the death or severe injury of a loved one.

\section{Relatives’ Main Concerns for Justice}

Our main objective was to investigate whether a monetary award could symbolize an acknowledgment to victims' relatives by helping to satisfy relatives' psychological concerns. For that reason, we also wanted to know the main concerns and motivations of our representative sample of victims' relatives in respect of the legal process. Our respondents had gone through legal processes following the death or injury of their loved ones in order to seek compensation of economic losses and/or in criminal procedures. More specifically, therefore, we also asked them to express their main concerns regarding the legal process in relation to their own emotional recovery. Here we found clear differences between violent crimes and torts (study 1). Relatives of violent crime victims - in which the injuries were inflicted intentionally-said that, as far as their emotional recovery was concerned, it was most important for the perpetrator to be convicted and punished. On the other hand, secondary tort victims - in which the injuries were inflicted unintentionally-deemed it most important to their emotional recovery for their economic losses to be compensated swiftly, but said even more often that they would be helped most if the harm-doer were to admit fault, recognize their losses, or apologize. $^{21}$ These findings suggest that compensation of economic harm alone may be an inadequate response to this unintentional harm (cf. Okimoto and Tyler 2007). Interestingly, we found there to be no difference between secondary victims of violent crime and secondary victims of tort with respect to our main findings on awards for emotional harm and that both groups equally appreciated that an award could help meet their psychological needs. ${ }^{22}$ Our findings suggested that relatives of victims of tort and violent crime regarded an award for emotional harm as representing a symbolic acknowledgment of their emotional loss and the rule violation (by the harm-doer and by society).

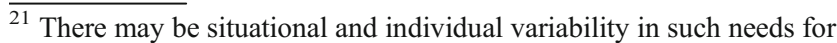
an apology from the harm-doer. This corresponded with another finding in study 1 that a large majority of relatives of victims of tort (but not of violent crime) would welcome a letter from the offender.

${ }^{22}$ Our finding that victims' relatives valued the involvement of the victim compensation fund in offering the award could also suggest that they would perceive such an award as a welcome community response, reaffirming the societal boundaries that underlie the criminal laws that have been broken (Tyler et al. 1997; Darley and Pittman 2003).
} 


\section{Conclusion}

Our results indicate that close relatives of fatally or seriously injured tort and violent crime victims perceive a monetary award for the emotional harm they have suffered as a positive response to the death or severe injury of their loved one. Our results suggest that people who have experienced the loss or severe injury of a loved one may be seeking acknowledgement of their emotional losses and the norm violation. Our findings provide support for the view that a modest monetary award may help meet secondary victims' psychological concerns. Results suggested that victims' family members viewed a monetary award as a means to an end, rather than as an end in itself. It seems that money can symbolize acknowledgment to victims' relatives.

Our studies yielded conflicting findings as to whether relatives preferred standardization or individuation of amounts. In either case, it could be particularly important to address relatives' non-monetary concerns by means of the manner in which the award is offered, given that our results support the view that the value of a monetary award is in the gesture. Our (qualitative) findings on the importance of the manner in which monetary awards are offered may also be relevant with respect to the provision of monetary compensation for other forms of non-economic (and even economic) harm. Our findings tie in with debates on the limitation of tort awards in the sense that they indicate that plaintiffs may also feel a need for a symbolic message acknowledging the gravity of their emotional losses and the rule violation (in addition to punishment of criminal offenders and compensation of economic losses) and that modest amounts and/or apologies may be a viable way to address these non-monetary concerns.

Our research may represent an important first step in understanding how close relatives of crime and tort victims view monetary awards for non-economic harm. We should be aware that there may be cultural and societal factors influencing claimants' views on such monetary awards. Future research in other jurisdictions on samples of people who have received awards for non-economic harm could be valuable, even though such attempts could once again be hindered by recruitment problems.

Acknowledgments The research featured in this paper was commissioned by the Dutch Ministry of Justice and supported by funds from the National Justice Research Center of the Dutch Ministry of Justice. We are grateful to the family members who were willing to share their experiences and views. We would like to thank Annemarie ten Boom of the National Justice Research Center; colleagues Liesbeth Claassen of EMGO Institute, VU University Medical Center, Amsterdam; and Nieke Elbers, Kiliaan van Wees, and David Bruinvels of VU University Amsterdam, TNS NIPO which managed the panel of respondents and online administration of the questionnaire, as well as the members of the Advisory Committee supervising our research. We also benefited from helpful comments from reviewers and participants at the Conference of Empirical Legal Studies 2010 and at a Non-Adversarial Justice conference 2010, Australia.

Open Access This article is distributed under the terms of the Creative Commons Attribution Noncommercial License which permits any noncommercial use, distribution, and reproduction in any medium, provided the original author(s) and source are credited.

\section{Appendix}

A copy of the entire questionnaire and interview protocol (in Dutch) can be obtained from the authors. Details about the section assessing the context of respondents' experiences and concerns in the legal process in the aftermath of the death or injury of their family member are set out below. Items in the first part of this section asked about aspects of the legal process (did you experience this: yes/no) and how that aspect had (in the event of a "yes" answer) or could have (in the event of "no") contributed to their emotional recovery (on a scale ranging from 1 (definitely not) to 7 (definitely so) or no reply/not applicable). In this part of this section, the statements included below were worded in the past tense (e.g., "The responsible party/offender was found guilty by a court, or other institution"). In a second part of this section, respondents were asked to express which three aspects were or would have been most important to their own emotional recovery as set out below.

Please read all the answers carefully first.

Which of these aspects do you find most important for your own recovery?

- That a court (or other institution) finds the responsible party/offender guilty.

- That a court (or other institution) punishes or imposes a fine on the responsible party/offender.

- That the responsible party acknowledges his fault (swiftly).

- That the responsible party acknowledges legal liability (swiftly).

- That the responsible party apologizes.

- That the responsible party voluntarily pays a monetary amount for the emotional impact on me.

- That the responsible party expresses empathy.

- That the responsible party sufficiently realizes the consequences for the victim.

- That the responsible party sufficiently realizes the consequences for me as a close relative of the victim.

- That the responsible party's insurer provides for swift resolution of the (financial) losses.

- That the responsible party's insurer compensates the financial losses (loss of income and costs incurred). 
- That the responsible party's insurer pays attention to the emotional impact on me.

- That action is taken to prevent similar crimes/ accidents in the future.

- That it is clear to the outside world that someone else is responsible for the accident.

[Additional items for violent crimes:]

- That the Victim Support officer provides me with adequate support.

- That the police treat me correctly.

- That the police pay attention to the emotional impact on me as a family member.

- That the Public Prosecutor's Office treats me correctly.

- That the Public Prosecutor's Office pays attention to the emotional impact on me as a family member.

[Additions that were made by respondents included] "support and empathy from family, friends" etc., "my faith" and "an apology from the wrongdoer."

Table 3 Study 1-mean scores and standard deviations on separate items of scale assessing need for awards for emotional harm, $(n=463)$

\begin{tabular}{llc}
\hline & $\begin{array}{l}\text { Means } \\
\text { (standard } \\
\text { deviations) }\end{array}$ & $\begin{array}{l}\text { Times "no } \\
\text { reply/not } \\
\text { applicable" }\end{array}$ \\
\hline $\begin{array}{l}\text { Within the claim settlement process, I } \\
\text { missed attention being given to the } \\
\text { emotional consequences for me as a }\end{array}$ & 4.89 (1.93) & 8 \\
relative. & & \\
$\begin{array}{l}\text { It has crossed my mind that the } \\
\text { responsible party should make a }\end{array}$ & 4.37 (2.07) & 8 \\
$\begin{array}{l}\text { financial sacrifice for the emotional } \\
\text { consequences the accident had for me. }\end{array}$ & \\
$\begin{array}{l}\text { I feel the lack of a financial commitment } \\
\text { for the emotional consequences that the } \\
\text { accident had for me as a relative. }\end{array}$ & 4.15 (2.14) & 13 \\
$\begin{array}{l}\text { The possibility of compensation for } \\
\text { emotional loss for family members } \\
\text { evokes positive feelings for me. }\end{array}$ & 5.04 (1.76) & 5 \\
$\begin{array}{l}\text { For me, the possibility of compensation } \\
\text { for emotional loss evokes mainly } \\
\text { negative feelings (reverse scored). }\end{array}$ & 5.21 (1.72) & 8 \\
$\begin{array}{l}\text { If compensation for emotional loss } \\
\text { existed, I would wish to receive it. }\end{array}$ & 5.20 (1.72) & 9 \\
\hline
\end{tabular}

Standard deviations appear in parentheses. All ratings were done on a seven-point scale (the higher the number, the higher the need). The same items used for relatives of parties injured in accidents were also used for relatives of violent crime victims, but with minor modifications in terminology ("crime" instead of "accident"; "offender" instead of "responsible party"). Adapted from Akkermans et al. (2008)

${ }^{a}$ The score on the contra-indicative item was reversed (outcomes on this item reflect that the provision of an award for emotional harm does not evoke negative feelings for respondents)
Table 4 Study 1 -modalities of offering an award for emotional harm, mean scores, and standard deviations for the total sample $(n=$ $463)$ and for relatives of violent crime victims separately $(n=51)$

\begin{tabular}{|c|c|c|}
\hline & $\begin{array}{l}\text { Total } \\
\text { sample }\end{array}$ & $\begin{array}{l}\text { Violent } \\
\text { crime }\end{array}$ \\
\hline \multicolumn{3}{|l|}{ It would be good... } \\
\hline $\begin{array}{l}\ldots \text { if the insurer of the responsible } \\
\text { party sent a personal letter } \\
\text { expressing empathy, before the } \\
\text { money was transferred }\end{array}$ & $5.65(1.57)$ & $5.45(1.74)$ \\
\hline $\begin{array}{l}\ldots \text { if the insurer of the responsible } \\
\text { party paid a home visit to express } \\
\text { empathy, before the money was } \\
\text { transferred }\end{array}$ & $4.20(1.94)$ & $3.27(2.15)$ \\
\hline $\begin{array}{l}\ldots \text { if the person responsible for the } \\
\text { accident sent a letter himself }\end{array}$ & $5.40(1.76)$ & $3.74(2.20)$ \\
\hline $\begin{array}{l}\ldots \text { if the person responsible for } \\
\text { the accident came to offer the } \\
\text { money himself }\end{array}$ & $2.96(1.94)$ & $1.96(1.71)$ \\
\hline $\begin{array}{l}\ldots \text { if the money was transferred without } \\
\text { any accompanying letter or home visit }\end{array}$ & $2.63(1.71)$ & $3.30(1.98)$ \\
\hline \multicolumn{3}{|l|}{$\begin{array}{l}\text { It would be good if the insurer of the } \\
\text { responsible party (prior to payment) } \\
\text { in a letter... }\end{array}$} \\
\hline $\begin{array}{l}\ldots \text { stated that the award had a symbolic } \\
\text { character as it cannot truly compensate } \\
\text { for the emotional impact of the accident } \\
\text { on close relatives. }\end{array}$ & $5.45(1.60)$ & $5.51(1.49)$ \\
\hline $\begin{array}{l}\ldots \text { emphasized the symbolic character } \\
\text { of the award by offering suggestions } \\
\text { for ways to spend the award. }\end{array}$ & $2.74(1.75)$ & $2.69(1.79)$ \\
\hline \multicolumn{3}{|l|}{ It would be good to suggest that... } \\
\hline $\begin{array}{l}\ldots \text { the money could be used for } \\
\text { the victim. }\end{array}$ & $5.27(1.41)$ & $5.58(1.50)$ \\
\hline $\begin{array}{l}\text {...the money could be used for a } \\
\text { trip or outing with family or friends. }\end{array}$ & $3.82(1.80)$ & $5.00(1.70)$ \\
\hline ...the money could be donated to charity. & $3.75(1.65)$ & $4.26(1.85)$ \\
\hline
\end{tabular}

Standard deviations appear in parentheses. All ratings were done on a seven-point scale (the higher the number, the more valued this aspect is). The same items used for relatives of parties injured in accidents were also used for relatives of violent crime victims, but with minor modifications in terminology ("compensation fund" instead of "the responsible party's insurer," "crime" instead of "accident"; "offender" instead of "responsible party"). Adapted from Akkermans et al. (2008)

\section{References}

Akkermans, A. J., Hulst, J. E., Claassen, E. A. M., Ten Boom, A., Elbers, N. A., Van Wees, K. A. P. C., et al. (2008). Slachtoffers en aansprakelijkheid. Een onderzoek naar behoeften, verwachtingen en ervaringen van slachtoffers en hun naasten met betrekking tot het civiele aansprakelijkheidsrecht, Deel II, Affectieschade [Victims and liability. A study of the needs, expectations and experiences of victims and those close to them in relation to civil liability law, Part II, Affectionate Damage]. The Hague: WODC (National Justice Research Centre).

Avraham, R. (2005). Should pain-and suffering damages be abolished from tort law? More experimental evidence. University of Toronto Law Journal, 55, 941-979.

Baurmann, M. C., \& Schädler, W. (1991). Victims of reported crimetheir expectations, needs and perspectives. An inquiry of crime 
victims concerning victim protection, victim support and mediation. In K. Kaiser \& J. Albrecht (Eds.), Victims and criminal justice. Max-Planck Institute: Freiburg.

Bismark, M., Dauer, E., Paterson, R., \& Studdert, D. (2006). Accountability sought by patients following adverse events from medical care: The New Zealand experience. Canadian Medical Association Journal, 175, 889-894.

Blumenthal, J. (2005). Law and the emotions: The problems of affective forecasting. 80 Ind. L. J., p. 155-238.

Bona, M., Mead, P., \& Lindenbergh, S. (2005). Personal injury compensation in Europe series: Fatal accidents \& secondary victims. UK: PEOPIL Research Group, XPL.

Caruso, E. M., Gilbert, D. T., \& Wilson, T. D. (2008). A wrinkle in time: Asymmetric valuation of past and future events. Psychological Science, 19, 796-801.

Darley, J. M., \& Pittman, T. S. (2003). The psychology of compensatory and retributive justice. Personality and Social Psychology Review, 7, 324-336.

Feldthusen, B., Hankivsky, O., \& Greaves, L. (2000). Therapeutic consequences of civil actions for damages and compensation claims by victims of sexual abuse. Canadian Journal of Women and Law, 12, 66-116.

Fisher, R. J. (1993). Social desirability bias and the validity of indirect questioning. Journal of Consumer Research, 20, 303-315.

Fiske, A. P., \& Tetlock, P. E. (1997). Taboo trade-offs: Reactions to transactions that transgress the spheres of justice. Political psychology, 18, 255-297.

Gilbert, D. T., Pinel, E. C., Wilson, T. D., Blumberg, S. J., \& Wheatley, T. P. (1998). Immune neglect: A source of durability bias in affective forecasting. Journal of Personality and Social Psychology, 75, 617-638.

Green, J. D., Burnette, J. L., \& Davis, J. L. (2008). Third-party forgiveness: (Not) Forgiving your close other's betrayer. Personality and Social Psychology Bulletin, 34, 407-418.

Hadfield, G. K. (2008). Framing the choice between cash and the courthouse: Experiences with the 9/11 Victim Compensation Fund. Law \& Society Review, 42, 645-682.

Hensler, D. R. (2003). Money talks: Searching for justice through compensation for personal injury and death. DePaul Law Rev, $53,417-456$

Hensler, D. R., Marquis, M. S., Abrahamse, F. A., Berry, H. S., Ebener, P. A., Lewis, G. E., et al. (1991). Compensation for accidental injuries in the United States. Santa Monica: RAND.

Huver, R. M. E., Van Wees, K. A. P. C., Akkermans, A. J., \& Elbers, N. A. (2007). Slachtoffers en aansprakelijkheid: Een onderzoek naar behoeften, verwachtingen en ervaringen van slachtoffers en hun naasten met betrekking tot het civiele aansprakelijkheidsrecht, Deel I, Terreinverkenning [Victims and liability. A study of the needs, expectations and experiences of victims and those close to them in relation to civil liability law. Part I, Exploratory study]. The Hague: WODC (National Justice Research Centre).

Johnson, B. R., Onwuegbuzie, A. J., \& Turner, L. A. (2007). Towards a definition of mixed methods research. Journal of Mixed Methods Research, 1, 115.

Lehman, D. R., Davis, C. G., DeLongis, A., Wortman, C. B., Bluck, S., Mandel, D. R., et al. (1993). Positive and negative life changes following bereavement and their relations to adjustment. Journal of Social and Clinical Psychology, 12, 90-112.

Lind, E. A., \& Tyler, T. R. (1998). The social psychology of procedural justice. New York: Plenum.

Lind, E. A., Macoun, R. J., Ebener, P. A., Felstiner, W. L. F., Hensler, D. R., Resnik, J., et al. (1990). In the eye of the beholder: Tort litigants' evaluations of their experiences in the civil justice system. Law \& Society Review, 24, 953-996.

Luntz, H. (2006). Assessment of damages for personal injury and death: General principles. Chatswood: Butterworths.
Maercker, A., \& Müller, J. (2004). Social acknowledgment as a victim or survivor: A scale to measure a recovery factor of PTSD. Journal of Traumatic Stress, 17, 345-351.

Maguire, M., \& Kynch, J. (2000). Public perceptions and victims' experiences of victim support: findings from the 1998 British Crime Survey. London: Home Office Research, Development and Statistics Directorate.

McClurg, A. J. (2005). Death sorrow: A story about loss and a new theory of wrongful death damages. BUL. Rev, 85, 1-51.

Middleton, W. F., Raphael, B. F., Burnett, P., \& Martinek, N. (1997). Psychological distress and bereavement. The Journal of Nervous and Mental Disease, 185, 447-453.

Miller, D. T. (1999). The norm of self-interest. American Psychologist, 54(12), 1053-1060.

Mulder, J. D. W. E. (2009). How do we compensate a victim's losses? An economic perspective. International Review of Victimology, $16,67-87$

Nadler, A., \& Liviatan, I. (2006). Intergroup reconciliation: Effects of adversary's expressions of empathy, responsibility and recipients' trust. Personality and Social Psychology Bulletin, 32, 459-470.

Okimoto, T. G., \& Tyler, T. R. (2007). Is compensation enough? Relational concerns in responding to unintended inequity. Group Processes \& Intergroup Relations, 10, 399-420.

Oswald, A. J., \& Powdthavee, N. (2008). Death, happiness and the calculation of compensatory damages. The Journal of Legal Studies, 37, 217-252.

Posner, E. A., \& Sunstein, C. R. (2005). Dollars and death. University of Chicago Law Review, 72, 537-598.

Risen, J. L., \& Gilovich, T. (2007). Target and observer differences in the acceptance of questionable apologies. Journal of Personality and Social Psychology, 92, 418-433.

Robbennolt, J. (2003). Apologies and legal settlement: An empirical examination. Michigan Law Review, 102, 460.

Robbennolt, J. K., Darley, J. M., \& MacCoun, R. J. (2003). Symbolism and incommensurability in civil sanctioning: Decision makers as goal managers. Brooklyn Law Rev., 68 , 1121.

Sale, J. E. M., Lohfeld, L. H., \& Brazil, K. (2002). Revisiting the quantitative-qualitative debate: Implications for mixed-methods research. Quality and Quantity, 36, 43-53.

Schatman, M., \& Sullivan, J. (2010). Whither suffering? The potential impact of tort reform on the emotional and existential healing of traumatically injured chronic pain patients. Psychological Injury and Law, 3, 182-202.

Schmitt, M., Gollwitzer, M., Forster, N., \& Montada, L. (2004). Effects of objective and subjective account components on forgiving. Journal of Social Psychology, 144, 465-485.

Schönbach, P. (1990). Account episodes: The management of escalation of conflict. New York: Cambridge University Press.

Shuman, D. W. (1994). The psychology of compensation in tort law. Kansas Law Review, 43, 39-77.

Strauss, A. L., \& Corbin, J. M. (1998). Basics of qualitative research [Online resource]: Techniques and procedures for developing grounded theory (2nd ed.). Thousand Oaks: Sage.

Stroebe, M. S., Hansson, R. O., Schut, H., \& Stroebe, W. (Eds.). (2008). Handbook of bereavement research and practice: Advances in theory and intervention. Washington, DC: American Psychological Association.

Struthers, C. W., Eaton, J., Santelli, A. G., Uchiyama, M., \& Shirvani, N. (2008). The effects of attributions of intent and apology on forgiveness: When saying sorry may not help the story. Journal of Experimental Social Psychology, 44, 983-992.

Sunstein, C. R. (2008). Illusory losses. The Journal of Legal Studies, 37, 157-190.

Swedloff, R., \& Huang, P. H. (2010). Tort damages and the new science of happiness. Indiana Law Journal, 85, 553-595. 
Ten Boom, A., \& Kuijpers, K. (2008). Behoeften van slachtoffers van delicten. Een systematische literatuurstudie naar behoeften zoals door slachtoffers zelf geuit. [The needs of crime victims. A systematic literature review of needs as expressed by victims themselves] The Hague: WODC/Boom Juridische uitgevers. O\&B 262. http://www.wodc.nl/onderzoeksdatabase/onderzoeknaar-de-achtergronden-van-wensen-die-slachtoffers-hebben.aspx.

Tetlock, P. E., Kristel, O. V., Elson, S. B., \& Lerner, J. S. (2000). The psychology of the unthinkable: Taboo trade-offs, forbidden base rates, and heretical counterfactuals. Journal of Personality and Social Psychology, 78, 853-870.
Tyler, T. R., \& Lind, E. A. (1992). A relational model of authority in groups. Advances in Experimental Social Psychology, 25, 115-191.

Tyler, T. R., Boeckmann, R. J., Smith, H. J., \& Huo, Y. J. (1997). Social justice in a diverse society. Boulder: Westview.

Wilson, T. D., \& Gilbert, D. T. (2005). Affective forecastingknowing what to want. Current Directions in Psychological Science, 14, 131-134.

Wortman, C. B., Battle, E. S., \& Lemkau, J. P. (1997). Coming to terms with the sudden, traumatic death of a spouse or child. In R. C. Davis, A. J. Lurigio, \& W. G. Skogan (Eds.), Victims of crime (pp. 108-133). Thousand Oaks: Sage. 